\title{
Diabetesesek dietoterápiájának és önmenedzselésének támogatása mobilapplikációk használatával
}

\author{
Szálka Brigitta ${ }^{1,2}$ - Kósa István dr. ${ }^{1,4}$ \\ Vassányi István dr. ${ }^{1}$. Mák Erzsébet dr. ${ }^{3}$ \\ ${ }^{1}$ Pannon Egyetem, Egészségügyi Informatikai Kutató-Fejlesztő Központ, Veszprém \\ ${ }^{2}$ Semmelweis Egyetem, Doktori Iskola, Budapest \\ ${ }^{3}$ Semmelweis Egyetem, Egészségtudományi Kar, Alkalmazott Egészségtudományi Intézet, \\ Dietetikai és Táplálkozástudományi Tanszék, Budapest \\ ${ }^{4}$ Honvédkórház, Balatonfüredi Kardiológiai Rehabilitációs Intézet, Balatonfüred
}

\begin{abstract}
A diabetes több pilléren nyugvó terápiájának sikerességéhez a gyógyszeres, illetve az inzulinterápián, esetenként a kórházi kezelésen túl elengedhetetlen fontosságú a helyes életmód elsajátítása, az életmód-terápia. A betegség önmenedzselésében, a helyes életmód, étrend kialakításában nyújtanak segítséget a mobilalkalmazások. A szerzők áttekintést adnak a hazai mobil- és/vagy online alkalmazások étrendi értékeléséról, összehasonlítva őket néhány jellemzó külföldi alkalmazással. A számos hasznos funkció mellett a dietetikai ajánlások alapján több hiányosságot is feltártnak, amelyek kiküszöbölése, illetve a hatékonyság és megbízhatóság validálását célzó klinikai vizsgálatok az orvosi evidenciák erősítését, valamint az ilyen jellegú alkalmazások további terjedését is elősegíthetik. Orv. Hetil., 2016, 157(29), 1147-1153.
\end{abstract}

Kulcsszavak: diabetes mellitus, táplálkozás, dietoterápia, telemedicina, egészségügyi informatikai applikációk

\section{Support of diabetes dietary management and self-management using mobile applications}

The key components of successful diabetes therapy are pharmacotherapy, hospital care and lifestyle education. Lifestyle education, self-management, and composing the right diet can be effectively supported with mobile applications. In this paper Hungarian mobile applications are reviewed and compared to some international competitors. Besides plenty of useful functions some deficiencies are identified, based on dietary recommendations. The related improvements together with clinical trials validating effectiveness and reliability can strengthen medical evidence as well as the penetration of such mobile applications.

Keywords: diabetes mellitus, nutrition, diet therapy, telemedicine, medical informatics applications

Szálka, B., Kósa, I., Vassányi, I., Mák, E. [Support of diabetes dietary management and self-management using mobile applications]. Orv. Hetil., 2016, 157(29), 1147-1153.

(Beérkezett: 2016. március 4.; elfogadva: 2016. május 11.)

\section{Rövidítések}

$\mathrm{BMI}=$ (body mass index $)$ testtömegindex; $\mathrm{BMR}=($ basal metabolic rate) alapanyagcsere; GI = (glycemic index $)$ glykaemiás index; GL = (glycemic load) glykaemiás terhelés; $\mathrm{HbA}_{\mathrm{lc}}=$ glikált hemoglobin; $\mathrm{kol}=$ koleszterin; $\mathrm{MUFA}=($ monounsaturat ed fatty acids) egyszeresen telítetlen zsírsav; PAF $=($ physical activity factor) fizikai aktivitás együtthatója; PUFA $=$ (polyunsaturated fatty acids) többszörösen telítetlen zsírsav; SFA = (saturated fatty acids) telített zsírsav; TFA = (trans fatty acids) transzzsírsav
A XXI. századra jellemző krónikus nem fertőző betegségek közül a diabetes epidemiológiai jelentősége vitathatatlanná vált. Az International Diabetes Federation 2015-ös közleménye szerint a világon 415 millió felnőtt él cukorbetegséggel, a gyermek diabetesesek száma mára meghaladja a félmilliót [1]. A diabetes terápiájában a gyógyszeres és/vagy inzulinkezelés mellett kiemelt szerepet kap az életmód-terápia. A diabetes mellitus progressziójának lassítása és a szövődmények kialakulásának 
elkerülése érdekében nélkülözhetetlen a helyes életmód és a megfelelő étrend elsajátítása.

Hazánkban a férfiak 62,8\%-a, a nók 60,7\%-a túlsúlyos vagy elhízott [2]. A praediabeteses állapot és a 2 -es típusú diabetes prevenciójának és terápiájának szempontjából elengedhetetlen a testtömegrendezés. Az életmódterápia, testtömegcsökkentés sikerességének feltétele, hogy a páciens kézbe tudja venni saját betegségének menedzselését, aminek része az önmonitorozás, életmódnapló vezetése $[3,4]$. Az étrendi napló vezetésének hatékonyságát több vizsgálat is igazolta [5-7]. Az önmenedzselés támogatásában az online vagy mobilfelületen múködő alkalmazások penetrációja és hatékonysága egyre kifejezettebb. A Diabeo applikáció hatékonyságát vizsgáló 6 hónapos klinikai vizsgálat során kimutatták, hogy az alkalmazást használó csoport $0,67 \%$-os $\mathrm{HbA}_{1 c^{-}}$ javulást ért el a kontrollcsoporthoz képest, és amelyik vizsgálati karban telekonzultációval is kiegészítették a kezelést, ott $0,91 \%$-os $\mathrm{HbA}_{1 c}$-csökkenést tapasztaltak [8].

A jelenlegi mobilalkalmazások több funkcióval rendelkeznek: lehetőséget kínálnak a fiziológiás paraméterek (testtömeg, vércukor, vérnyomás), a gyógyszerelés, illetve az alkalmazott inzulindózisok, az étrend naplózására és értékelésére [9]. A mobileszközök használata segítséget nyújthat a helyes életmód elsajátításában azáltal, hogy a mobileszközök velünk vannak mindennapi életünkben, szituációinkban, a rögzítés helyszínén számítják az egyes ételek, illetve étkezések tápanyagtartalmát, ezekról azonnali visszajelzést adnak. Az életmódnapló használatával a cukorbeteg felhasználó jobban megtanulhatja az elfogyasztott táplálék, továbbá az alkalmazott gyógyszerek és/vagy inzulindózisok hatását vércukorszintjére. Azok az életmódváltó programok sikeresebbek, ahol a páciens visszacsatolást is kap [10].

Mobilapplikációkat mindezek ellenére mégis kevesen használnak, a célpopuláció mindössze 1,2\%-a [11]. Ennek oka fóleg az, hogy a részletes napló kézi bevitele a felhasználói felületek nehézkes kezelhetősége miatt túl nagy idő- és energiaráfordítást igényel, valamint kisebb mértékben ugyan, de zavaró lehet a túl sok funkció. Ezt támasztja alá egy több mint 656 applikációt elemző vizsgálat, amelyben az 50 év feletti felhasználók szerint az applikációk funkcióinak növekedésével használhatóságuk csökken [12]. Eddig, különösen Magyarországon, meglehetősen kevés klinikai vizsgálatot végeztek a mobiléletmódnaplózás hatékonyságának és pontosságának validálása céljából. Egy nemrég lezajlott, $4 \times 20$ fös hazai vizsgálat azt találta, hogy megfelelő keresőfelületek esetén a táplálkozási naplózás időszükséglete napi 5 percre csökkenthető még a mobiltechnológiában nem jártas, idősebb betegek esetén is. A járóbeteg-vizsgálatban részt vevő páciensek által mért hyper- és hypoglykaemiás eredmények előfordulási gyakorisága a 3 hónapos tesztidőszak során kimutathatóan csökkent, ezenkívül 0,24\%-os átlagos $\mathrm{HbA}_{1 \mathrm{c}}$-csökkenés, 0,81 átlagos BMI-csökkenés történt, bár az eredmények a kis esetszám miatt nem szignifikánsak. A résztvevők által kitöltött kérdőívek alapján minden résztvevő ajánlaná ilyen program használatát másoknak, egynegyedük pedig arról számolt be, hogy kifejezetten élményt jelentett neki a naplózás [1315 ].

A Magyarországon, magyar nyelven elérhetó négy online és/vagy mobilalkalmazást [16-19] teszteltük, hasonlítottuk egymáshoz, illetve a nemzetközi piacon hasonló funkciókkal rendelkező mobilalkalmazásokhoz [20-23]. A négy külföldi alkalmazás kiválasztásának egyik szempontja, hogy szerepeljen köztük olyan, amely a magyar Kalóriabázis [17] online felületen múködő alkalmazáshoz hasonlóan alapvetően egészségeseknek készült, azonban kidolgozott tápláléknaplózó és fizikai aktivitást rögzító funkciója miatt praediabeteses és nem inzulinfüggő cukorbetegek számára is jól használható. Ilyen az online és mobilfelületen is múködő alkalmazás az Egyesült Államokban fejlesztett MyFitnessPal [20] és a svéd Lifesum [21]. A kiválasztás másik kritériuma, hogy az alkalmazások között szerepeljen kimondottan diabetesprofilú életmódnaplózást, fiziológiás paramétereket, gyógyszerelést, továbbá az inzulindózisok rögzítését magában foglaló funkció. Ilyen a svéd Triabetes [22] és az ausztriai MySugr program [23]. A külföldi alkalmazások azonban a táplálkozási kultúra különbségei miatt gyakorlatilag nem jelentenek használható alternatívát a hazai felhasználók számára, csak a funkcionális összehasonlítás miatt vontuk be azokat a tanulmányba. A tesztelés kimondottan dietetikai aspektusból történt. Azon diabeteseseknek készült alkalmazásokat, amelyek nem tartalmaznak étrendi naplót, illetve étrendi naplóra vonatkozó értékelést, nem értékeltük.

Az értékeléshez használt szempontrendszerünk kialakításához figyelembe vettük a mobilalkalmazások funkcióira vonatkozó szakirodalmat [24], ezek:

- alkalmazás hozzáférhetősége,

- anamnézis részletessége,

- tápláléknaplózás alapját jelentő adatbázis megbízhatósága,

- étrendi napló energia- és tápanyagtartalmának értékelése,

- kapcsolatteremtés egészségügyi szakemberekkel, betegtársakkal.

\section{A magyar nyelven elérhető online és mobilalkalmazások}

A magyar nyelven elérhető online (webes) és mobilalkalmazások kétségtelen előnye, hogy lehetővé teszik az anyanyelven, a hazai kultúrának megfelelő nyersanyagok, élelmiszerek és ételek választásából vett naplózást. Az alkalmazások közül a Kalóriabázis online felületen múködik, létezik mobilváltozata is, utóbbi használata azonban a felhasználó számára nehézkes lehet. A Kalóriaguru csak interneten elérhető alkalmazás, ellenben megfelelő méretü okostelefonnal vagy tablettel használható a webes felület is naplózásra. A Menta és Lavinia mobilalkalma- 
zásként múködnek. A Lavinia applikáció jelenleg ingyenesen tesztelhető. A magyar nyelven elérhető alkalmazások mindegyike rendelkezik ingyenes funkciókkal. A Kalóriabázis alkalmazásába nemrég került be prémium (fizetős) szolgáltatásként a weboldal szakértőjével való kapcsolattartás lehetősége. Azonban a program továbbra is lehetóséget ad a felhasználónak arra, hogy életmódnaplóját megossza orvosával, dietetikusával.

A hazai alkalmazások széles körú ingyenes szolgáltatásaival szemben a külföldi alkalmazásoknak csak az alapfunkciói érhetők el ingyenesen, így például a részletes étrendi elemzést már prémium szolgáltatásként tudják megvásárolni a felhasználók.

\section{Anamnézis rögzítése}

Az étrendi értékelés pontos értékeléséhez szükséges az anamnesztikus adatok minél részletesebb rögzítése és ehhez kapcsolódóan a testtömeg-változtatásra vagy testsúlytartásra vonatkozó célok meghatározása. A hazai alkalmazások a testtömegvesztésre koncentrálnak. Rendszerint legördülő menü segítségével tudja a felhasználó beállítani a kívánt testtömeget. Fontos beépített funkció, ha a felhasználó túl magas vagy túl alacsony célértékeket határoz meg, erre figyelmeztető üzenetet kap. A programok tesztelése során ilyen funkcióval csak a MyFitnessPal alkalmazásban találkoztunk (1. táblázat).

\section{A tápláléknaplózás és az étrendi értékelés alapjául szolgáló adatbázis megbízhatósága, bővíthetősége}

Az étrendi napló rögzítésének feltétele, hogy a nyersanyag-, élelmiszer- és receptadatbázisban szerepeljenek a felhasználó által rögzíteni kívánt tételek. Az adatbázis megbízhatósága meghatározó tényező a naplózott tételek és étkezések értékelésének szempontjából. A hazai szakmai gyakorlat elsősorban az Új tápanyagtáblázat [25] adatait használja energia- és tápanyagszámításra, esetleg kiegészítve külső forrásokkal, mint például a Lavinia esetében a US Department of Agriculture National Nutrient Database for Standard Reference adatbázissal, illetve esetenként a dietetikus szakértők az élelmiszergyártóktól vett energia- és tápértékadatokkal is bővítik az adatbázist.

A vizsgált mobilalkalmazások egymástól eltérő gyakorlatot alkalmaznak arra az esetre, amikor egy nyersanyag, élelmiszer, étel vagy ital nem található az adatbázisban. A Kalóriabázis és a Kalóriaguru alkalmazásban a felhasználó számára is elérhető az adatbázis-bővítés (új táplálékok, receptek hozzáadására) dietetikus közremúködése nélkül. Ezekben az alkalmazásokban találtunk olyan élelmiszereket, amelyeknél az energiatartalmat a felhasználók megadták, azonban a makrotápanyag-értékek bevitele elmaradt. Ennélfogva az adott táplálék, a vonatkozó étkezés és nap értékelése is hibás. A Lavinia programban a dietetikus szakértő a felhasználók által beküldött kérések alapján, ha szükségesnek ítéli meg, kiegészíti az adatbázist. Így az adatbázisba bevitt adatok megbízhatók és részletesek. Mind a felhasználók, mind a szakértők számára jó gyakorlat, ha az adatbázisban nem talált nyersanyagokat, ételeket vagy italokat hasonló táplálékkal helyettesítjük.

A MyFitnessPal zöld pipával jelzi a naplózás során azokat a nyersanyagokat, ételeket, italokat, amelyeknek minden tápanyagértékét tartalmazza az adatbázis, ezeknek a jelölt tételeknek az előnyben részesítését javasolja a felhasználó számára. Hasonló megoldás a hazai alkalmazásokban nem található.

1. táblázat |Az anamnézis rögzített elemeinek összehasonlítása

\begin{tabular}{|c|c|c|c|c|c|c|c|c|c|}
\hline \multicolumn{2}{|c|}{ Online/mobil applikáció } & \multirow{2}{*}{ 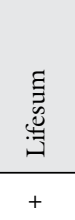 } & \multirow{2}{*}{ 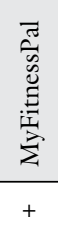 } & \multirow{2}{*}{ 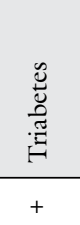 } & \multirow{2}{*}{$\begin{array}{l}\frac{\dot{b}}{5} \\
\sum^{\infty} \\
+\end{array}$} & \multirow{2}{*}{ 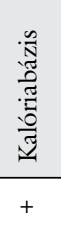 } & \multirow{2}{*}{ 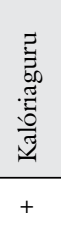 } & \multirow{2}{*}{$\frac{\stackrel{\pi}{\Xi}}{+}$} & \multirow{2}{*}{$\frac{\underset{\Xi}{\leftrightarrows}}{+}$} \\
\hline Személyes adatok & Nem & & & & & & & & \\
\hline & Életkor & + & + & + & + & + & + & + & + \\
\hline \multirow{4}{*}{$\begin{array}{l}\text { Antropometriai } \\
\text { paraméterek }\end{array}$} & Testtömeg & + & + & + & - & + & + & + & + \\
\hline & Testmagasság & + & + & + & - & + & + & + & + \\
\hline & Derékkörfogat & - & - & - & - & - & + & - & - \\
\hline & Csípókörfogat & - & - & - & - & - & + & - & - \\
\hline \multirow[t]{2}{*}{ Kórelőzmény } & Jelenlegi betegség & - & - & + & + & - & - & + & + \\
\hline & Korábbi betegség, mútét & - & - & + & - & - & - & + & - \\
\hline \multicolumn{2}{|c|}{ Étrendre vonatkozó orvosi javaslat } & - & - & - & - & - & - & - & + \\
\hline \multicolumn{2}{|c|}{ Testtömeg csökkentés/növelés/tartás } & +-- & +++ & +-+ & --- & +++ & +++ & +++ & +++ \\
\hline \multicolumn{2}{|c|}{ Aktivitási szint (például aktív, mérsékelten stb.) } & + & + & + & - & + & + & + & + \\
\hline
\end{tabular}




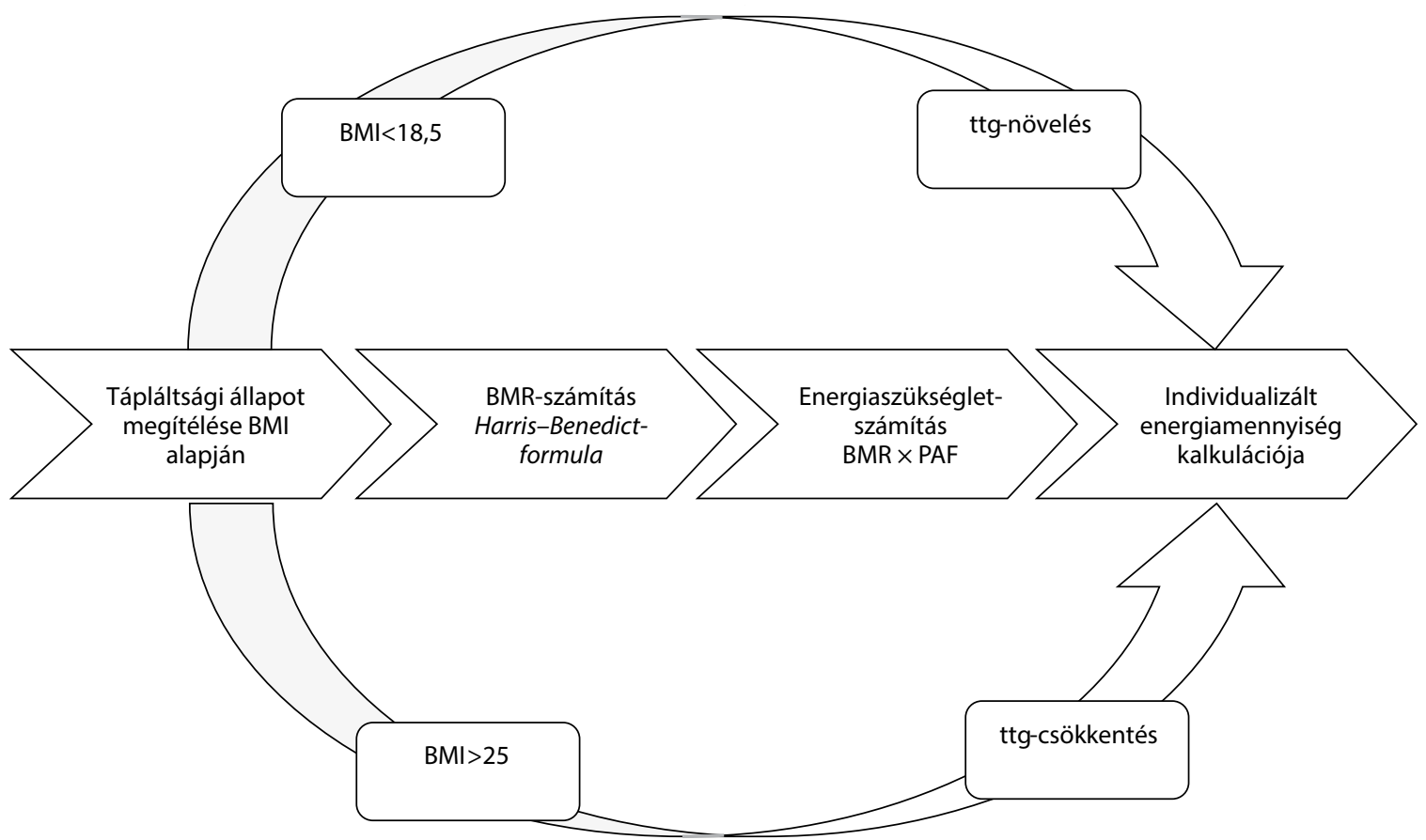

1. ábra Az étrend energia- és tápanyagtartalmának meghatározása a Lavinia programban - egyszerúsített workflow
BMI = (body mass index $)$ testtömegindex; BMR = (basal metabolic rate $)$ alapanyagcsere; PAF = (physical activity factor $)$ fizikai aktivitás együtthatója;
ttg = testtömeg

\section{Az étrend energiatartalmának meghatározása és értékelése}

Minden felhasználó számára fontos, hogy naplózott étrendjének energiatartalmáról a számára javasolt étrend energia- és tápanyagtartalmának tükrében visszajelzést kapjon. A javasolt étrend energiatartalmát az anamnézis adatai alapján határozzák meg az alkalmazások. Az alapanyagcsere-számítást, a fizikai aktivitást és a testtömegváltoztatási célokat is figyelembe véve javaslatot tesznek az étrend energia- és makrotápanyag-tartalmára vonatkozóan (1. ábra).

\section{$\mathrm{Az}$ étrend makrotápanyag-tartalmának értékelése}

A makrotápanyagok elosztása az Amerikai Diabetes Társaság ajánlása szerint individualizáltan kezelendő [26]. A makrotápanyagok általános értékeléséhez, energiaszázalékos elosztására több ajánlást is találunk. Ezek alapján - amennyiben polimorditás vagy szövődmény nem korlátozza - a makrotápanyagok megoszlása diabetesben: 15-20 energiaszázalék fehérje, 50-55 energiaszázalék szénhidrát, 30(-35) energiaszázalék zsír [27, 28].

A fehérje, szénhidrát, zsír megosztását a felhasználók maguk állíthatják be a Triabetes, Lifesum, Kalóriabázis, Kalóriaguru alkalmazásokban. Ez a flexibilis szolgáltatás azonban annak a veszélyét hordozza, hogy a felhasználók túl alacsony vagy éppen túl magas határértékeket ál- lítanak be maguknak, amire jelenleg nem kapnak figyelmeztetést.

Bár a makrotápanyagok közül cukorbetegek számára legfő́képp a szénhidráttartalom megjelenítése lényeges, a betegség progressziójának lassítása, valamint a cardiovascularis és veseszövődmény mérséklése érdekében fontos, hogy a zsír- és fehérjebevitelról is visszajelzést kapjon a felhasználó. Diabeteses páciens számára nélkülözhetetlen, hogy az alkalmazás megjelenítse az adott étkezés alkalmával elfogyasztott vagy elfogyasztani kívánt táplálék összegzett szénhidráttartalmát. Vagyis a szénhidrátokra vonatkozó értékelés a naplózott tételek, az étkezések és a napok szintjén is megvalósuljon. Inzulinnal kezelt cukorbetegeknek mindez az alkalmazandó inzulindózis miatt is szükséges információ. A Menta és a Kalóriabázis kivételével ezt mindegyik magyar alkalmazás lehetôvé teszi.

$\mathrm{Az}$ egyes nyersanyagok, élelmiszerek, ételek vércukoremelő képességét azok glykaemiás indexével jellemezzük $[29,30]$. A diabetes dietoterápiájában a lassú, egyenletes vércukor-emelkedést, ezáltal kiegyensúlyozott vércukorszintet eredményező alacsony, $55 \%$ alatti glykaemiás indexû́ táplálékok preferálandók [28, 30].

A szénhidrátok mennyiségi és minőségi értékelését magában egyesítő mutató a glykaemiás terhelés (GL). A GL az elfogyasztott táplálék GI-je és szénhidrátmenynyisége alapján számított érték [29]. A GL jól kifejezi a páciens számára, hogy az alacsony GI-jü táplálékokból (például magas rosttartalmú kenyerek, szárazhüvelyesek) is csak az étrend szénhidráttartalmának határai között 
ehet, illetve, hogy a magas GI-jü táplálékok kis mennyiségú fogyasztása is időnként megengedett. A vizsgált összes hazai és külföldi alkalmazás közül csak a Lavinia ad információt a naplózott tételek glykaemiás indexéról, illetve az étkezések individualizált GL-értékeléséről.

A vízben oldódó, viszkózus rostok gélszerü anyagot képeznek, ami fékezi az emésztőenzimek aktivitását, elnyújtják a szénhidrátok felszívódását [31, 32]. Ezért hasznos, ha a felhasználó rostbevitelről is visszajelzést kap (jelenleg szintén csak a Laviniában elérhető).

A szénhidrátok részletes értékelése során a naplózott táplálékok cukortartalmának megjelenítése is fontos, erről a külföldi alkalmazások közül a MyFitnesPal alapszolgáltatása és a Lifesum fizetős verziója ad információt, egyik magyar alkalmazásban sincs ilyen funkció.

A diabetes szív- és érrendszeri szövődményeinek prevenciója vagy a már manifesztálódott szövődmény diétás kezelése szempontjából hasznos, ha a felhasználó a naplózott tételek, étkezések és a napi étrendi értékelés szintjén az SFA, MUFA, PUFA, TFA zsírsavak fogyasztásáról és a koleszterinbevitelről is visszajelzést, értékelést kapjon $[27,28,33,34]$.

Kiváltképp igaz ez a hazai lakosság vonatkozásában. A 2009-es Országos Táplálkozás és Tápláltsági Állapot Vizsgálat eredményei alapján [35] elmondhatjuk, hogy a hazai lakosság zsírbevitele minden korosztályban felette van mind a hazai, mind az Egészségügyi Világszervezet által kiadott, illetve amerikai ajánlásoknak [36-38]. Az étrend zsírtartalmának mennyiségén túl sokkal fontosabb a zsírok minőségi összetétele, ennek jelentőségét az Amerikai Diabetes Társaság B szintű orvosi evidenciaként kezeli [26]. Jelenleg ilyen funkció a MyFitnessPal alkalmazásban alapszolgáltatásként, a Lifesumban pedig fizetős szolgáltatásként érhető el, a hazai applikációk egyike sem tartalmazza.

Amennyiben a diabetes mellé veseszövődmény is társul, fontos, hogy a páciens a naplózott tételek, étkezések, illetve a napi étrend fehérjebeviteléról is kapjon visszajelzést [28]. Ez a funkció a magyar alkalmazások közül a Kalóriabázisban és a Laviniában is megtalálható.

\section{Mikrotápanyagok értékelése}

A diabetes szövődményeinek prevenciója és a már meglévő szövődmények, társbetegségek kezelése szempontjából is hasznos, ha a mikrotápanyagokról is visszajelzést, értékelést kap a páciens. Többek között az étrend nátriumtartalmának visszajelzése az egészséges étrendben is alapvető, de kiváltképp lényeges, ha a diabeteses páciens cardiovascularis betegséggel vagy veseelégtelenséggel is küzd. Köszvényes betegek számára a naplózott tételek és az étrend purintartalmának értékelése szolgáltat még lényeges információt. Erről jelenleg egyik vizsgált alkalmazás sem ad visszajelzést [28].

A mikrotápanyagok értékelésének nehézsége egyrészt az adatbázis hiányosságaiból adódik. A magyar adatforrások - az Új tápanyagtáblázat vagy a gyártóktól vett energia- és tápanyagérték-adatok - esetenként, különösen az egészségtudatos felhasználók által kedvelt élelmiszerek vonatkozásában nem tartalmazzák a teljes tápanyagprofilt. A felhasználók számára mikro- és makrotápanyagok értékelésének megértését a túl sok többletinformáció nehezíti, ezért előnyös, ha a felhasználó szabadon állíthatja be, mely tápanyagokat szeretné látni (2. táblázat).

\section{Zavaró információk}

Az alkalmazások tesztelése során több zavaró információt is találtunk. Ilyen a Menta alkalmazásban az összes étkezés napi átlagértéke, heti, havi, negyedévi kalóriamennyiség. Mindezek az étrend és a dietoterápia szempontjából nem tartalmaznak releváns információkat, ugyanakkor a felhasználók befogadóképességét túlterhelhetik. Az egyes étkezések szénhidráttartalmának, mennyiségének és minőségének - különösen cukorbetegeknél - alkalmazkodnia kell a szervezet inzulinérzékenységéhez, éppen ezért a szakmai ajánlások alapján az egyes étkezések energia- és szénhidrátértékei eltérők, az étkezések átlagos energiatartalma ezért nem releváns információ $[27,28]$.

Továbbá egészségtudatos felhasználók számára a különböző fizikai aktivitású napok figyelembevétele nélkül nem informatív csupán napi energia-átlagértékeket számolni.

\section{Szakértői értékelés, közösségi kapcsolatteremtés}

Az alkalmazások közül a Kalóriabázis, a Kalóriaguru és a Lavinia program lehetővé teszi, hogy naplózott adataikhoz hozzáférhessen az orvos, a dietetikus vagy más egészségügyi szakember. Az alkalmazás használatával a kontrollvizsgálatokra kész naplókkal érkezik a beteg. Az alkalmazások lehetőséget adnak arra, hogy két kontrollvizsgálat között is az orvos vagy a dietetikus kövesse betege állapotának, életmódjának alakulását, online konzultáljanak.

Különösen fogyni vágyó betegek életmód-változtatását támogatják azok a funkciók, amelyekkel étrendjüket megoszthatják más felhasználóval vagy egy „fogyótárssal".

A MySugr gyermekeknek készült Junior verzióját úgy tervezték, hogy a gyermek táplálék- és vércukornaplójáról a szülő értesítést kapjon (3. táblázat).

\section{Következtetések}

A magyar nyelven elérhető, diabetest támogató mobilalkalmazások előnye, hogy a felhasználók anyanyelvükön, étkezési kultúrájuknak megfelelő nyersanyag-, élelmiszer- és receptadatbázis segítségével rögzíthetik elfogyasztott táplálékukat. 
2. táblázat |Az étrend energia- és tápanyagtartalmának összehasonlító értékelése

\begin{tabular}{|c|c|c|c|c|c|c|c|c|c|c|c|c|c|c|c|c|c|c|c|c|c|c|c|c|}
\hline \multirow{2}{*}{$\begin{array}{l}\text { Alkalmazás } \\
\text { Értékelés szintje/tápanyag }\end{array}$} & \multicolumn{3}{|c|}{ Lifesum } & \multicolumn{3}{|c|}{ MyFitnessPal } & \multicolumn{3}{|c|}{ Triabetes } & \multicolumn{3}{|c|}{ MySugr } & \multicolumn{3}{|c|}{ Kalóriabázis } & \multicolumn{3}{|c|}{ Kalóriaguru } & \multicolumn{3}{|c|}{ Menta } & \multicolumn{3}{|c|}{ Lavinia } \\
\hline & $\begin{array}{l}\overline{\tilde{A}} \\
\bar{z}\end{array}$ & 芯 & 䓌 & $\begin{array}{l}\overline{\vec{z}} \\
\bar{z}\end{array}$ & 芯 & 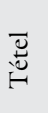 & $\begin{array}{l}\overline{\vec{a}} \\
\bar{z}\end{array}$ & 芯 & 营 & $\begin{array}{l}\overrightarrow{\vec{z}} \\
\stackrel{\vec{z}}{z}\end{array}$ & 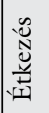 & 窇 & $\begin{array}{l}\overline{\vec{A}} \\
\bar{z}\end{array}$ & 荧 & 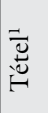 & $\begin{array}{l}\overline{\tilde{A}} \\
\bar{z}\end{array}$ & 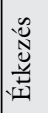 & 离 & $\begin{array}{l}\overline{\vec{u}} \\
\bar{z}\end{array}$ & 芯 & 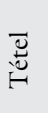 & $\begin{array}{l}\overline{\vec{a}} \\
\bar{z}\end{array}$ & 芯 & $\overline{\underline{U}}$ \\
\hline $\mathrm{E}$ & + & + & + & + & + & + & + & + & + & - & - & - & + & + & - & + & + & + & + & + & + & + & + & + \\
\hline $\mathrm{F}$ & + & + & + & + & + & + & + & + & + & - & - & - & + & - & - & + & + & + & - & - & - & + & + & + \\
\hline ZS & + & + & + & + & + & + & + & + & + & - & - & - & + & - & - & + & + & + & - & - & - & + & + & + \\
\hline SFA & * & * & * & + & - & + & - & - & - & - & - & - & - & - & - & - & - & - & - & - & - & - & - & - \\
\hline MUFA & * & * & * & + & - & + & - & - & - & - & - & - & - & - & - & - & - & - & - & - & - & - & - & - \\
\hline PUFA & * & * & * & + & - & + & - & - & - & - & - & - & - & - & - & - & - & - & - & - & - & - & - & - \\
\hline TFA & - & - & - & + & - & + & - & - & - & - & - & - & - & - & - & - & - & - & - & - & - & - & - & - \\
\hline kol & * & * & * & + & - & + & - & - & - & - & - & - & - & - & - & - & - & - & - & - & - & - & - & - \\
\hline $\mathrm{CH}$ & + & + & + & + & + & + & - & - & - & - & - & - & + & - & - & + & + & + & - & - & - & + & + & + \\
\hline Cukor & * & * & * & + & - & + & - & - & - & - & - & - & - & - & - & - & - & - & - & - & - & - & - & - \\
\hline Rost & * & * & * & + & - & + & - & - & - & - & - & - & - & - & - & - & - & - & - & - & - & + & + & + \\
\hline Víz & + & + & + & - & - & - & - & - & - & - & - & - & - & - & - & - & - & - & - & - & - & - & - & - \\
\hline $\mathrm{Na}$ & * & * & * & + & + & + & - & - & - & - & - & - & + & - & - & - & - & - & - & - & - & + & - & - \\
\hline $\mathrm{K}$ & * & * & * & + & - & + & - & - & - & - & - & - & + & - & - & - & - & - & - & - & - & + & - & - \\
\hline $\mathrm{P}$ & - & - & - & - & - & - & - & - & - & - & - & - & + & - & - & - & - & - & - & - & - & + & - & - \\
\hline $\mathrm{Ca}$ & - & - & - & + & - & + & - & - & - & - & - & - & + & - & - & - & - & - & - & - & - & + & - & - \\
\hline $\mathrm{Fe}$ & - & - & - & + & - & + & - & - & - & - & - & - & + & - & - & - & - & - & - & - & - & - & - & - \\
\hline A-vitamin & - & - & - & + & - & + & - & - & - & - & - & - & + & - & - & - & - & - & - & - & - & - & - & - \\
\hline C-vitamin & - & - & - & + & - & + & - & - & - & - & - & - & + & - & - & - & - & - & - & - & - & - & - & - \\
\hline
\end{tabular}

*Emelt díjas szolgáltatás.

${ }^{1}$ A naplózott összetevők energia- és tápanyagtartalma esetenként megjelenik, azonban nem a naplózott mennyiségre vonatkoztatva. $\mathrm{CH}=$ szénhidrát; $\mathrm{E}=$ energia; $\mathrm{F}$ = fehérje; kol = koleszterin; MUFA = (monounsaturated fatty acids) egyszeresen telítetlen zsírsav; PUFA = (polyunsaturated fatty acids) többszörösen telítetlen zsírsav; SFA = (saturated fatty acids) telített zsírsav; TFA = (trans fatty acids) transzzsírsav; $\mathrm{ZS}=$ zsír.

$\mathrm{Az}$ alkalmazások tesztelése után megállapíthatjuk, hogy cukorbetegség diétájának önmenedzselésében azok az alkalmazások használhatók jól, amelyek a szénhidrátok mennyiségi értékelésén túl azok vércukorszint-emeló hatásáról is informálják a felhasználót. A vizsgált magyar alkalmazásokban hiányzik a zsírok részletes értékelése,

3. táblázat | Szakértői értékelés, közösségi kapcsolatteremtés lehetőségének összehasonlítása a különböző mobilapplikációkban

\begin{tabular}{|c|c|c|c|c|c|c|c|c|}
\hline Alkalmazás/funkciók & 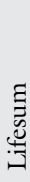 & 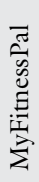 & 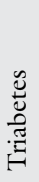 & 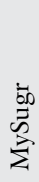 & 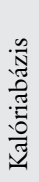 & 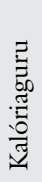 & $\stackrel{\pi}{\stackrel{\pi}{U}}$ & : \\
\hline $\begin{array}{l}\text { Orvos/dietetikus- } \\
\text { páciens összekapcsolás }\end{array}$ & - & - & + & + & + & + & - & + \\
\hline $\begin{array}{l}\text { A napló megosztása más } \\
\text { felhasználókkal }\end{array}$ & - & - & - & + & + & + & - & + \\
\hline Fórum & - & - & - & + & + & + & - & + \\
\hline Közösségi oldal & + & + & + & + & + & + & + & - \\
\hline
\end{tabular}

ami a diabetes szív- és érrendszeri szövődményeinek prevenciója vagy a már manifesztálódott szövődmény diétás kezelése szempontjából hasznos funkció. Mivel a diabeteses betegek jellemzően társbetegséggel $[39,40]$ vagy szövődménnyel is küzdenek, a polimorbiditás kezelése, illetve ezekre a betegségekre vonatkozó visszajelzések, értékelések jelenthetik a mobilapplikációk egyik jövőbeli kívánatos fejlesztési vonalát. Mindezen funkciók fejlesztéséhez szorgalmazzuk a további validációs célú vizsgálatok indítását, amelyek e funkciók hatékonyságáról további evidenciát tudnának szolgáltatni.

Anyagi támogatás: A közlemény megírása, illetve a kapcsolódó kutatómunka anyagi támogatásban nem részesült.

Szerzői munkamegosztás: Sz. B.: A kézirat megszövegezése. K. I.: Orvosi tanácsadás. V. I.: Informatikai tanácsadás. M. E.: Dietetikai tanácsadás. A cikk végleges változatát valamennyi szerző elolvasta és jóváhagyta.

Érdekeltségek: A szerzőknek nincsenek érdekeltségeik. 


\section{Irodalom}

[1] International Diabetes Federation: IDF Diabetes Atlas, Seventh Edition, 2015. http://www.diabetesatlas.org/component/attac hments/?task=download\&id=116

[2] Martos, É., Kovács, V. A., Bakacs, M., et al.: Hungarian diet and nutritional status survey - the OTAP2009 study. I. Nutritional status of the Hungarian population. [Országos Táplálkozás és Tápláltsági Állapot Vizsgálat - OTÁP2009. I. A magyar lakosság tápláltsági állapota.] Orv. Hetil., 2012, 153(26), 1023-1030. [Hungarian]

[3] Wing R. R.: Behavioral approaches to the treatment of obesity. In: Bray, G. A., Bouchard, C. (eds.): Handbook of obesity. Marcel Dekker, New York, 2004.

[4] Smith, C. F., Wing, R. R.: New directions in behavioral weightloss programs. Diabetes Spectrum, 2000, 13(3), 142.

[5] Sperduto, W. A., Thompson, H. S., O'Brien, R. M.: The effect of target behavior monitoring on weight loss and completion rate in a behavior modification program for weight reduction. Addict. Behav., 1986, 11(3), 337-340.

[6] Boutelle, K. N., Kirschenbaum, D. S., Baker, R. C., et al.: How can obese weight controllers minimize weight gain during the high risk holiday season? By self-monitoring very consistently Health Psychol., 1999, 18(4), 364-368.

[7] Baker, R. C., Kirschenbaum, D. S.: Weight control during the holidays: highly consistent self-monitoring as a potentially useful coping mechanism. Health Psychol., 1998, 17(4), 367-370.

[8] Charpentier, G., Benhamou, P. Y., Dardari, D., et al: The Diabeo software enabling individualized insulin dose adjustments combined with telemedicine support improves $\mathrm{HbA}_{\mathrm{lc}}$ in poorly controlled type 1 diabetic patients: a 6-month, randomized, openlabel, parallel-group, multicenter trial (TeleDiab 1 Study). Diabetes Care, 2011, 34(3), 533-539.

[9] Shah, V. N., Garg, S. K.: Managing diabetes in the digital age. Clin. Diab. Endocrinol., 2015, 1, 16.

[10] Artinian, N. T., Fletcher, G. F., Mozaffarian, D., et al.: Interventions to promote physical activity and dietary lifestyle changes for cardiovascular risk factor reduction in adults: A scientific statement from the American Heart Association. Circulation, 2010, 122(4), 406-441.

[11] Top 14 diabetes app publishers capture 65\% market share of the diabetes app market. Available from: http://research2guidance. com/2014/03/20/top-14-diabetes-app-publishers-capture65-market-share-of-the-diabetes-app-market-2/

[12] Arnold, M., Quade, M., Kirch, W.: Mobile applications for diabetics: A systematic review and expert-based usability evaluation considering the special requirements of diabetes patients age 50 years or older. J. Med. Internet Res., 2014, 16(4), el04.

[13] Kósa, I., Vassányi, I., Pintér, B., et al.: Clinical experiences with a mobile diet logging application. European e-Cardiology \& e-Health Congress, Bern, 2014.

[14] Kósa, I., Vassányi, I., Szálka, B., et al.: Change of physiological parameters during use of lifestyle supporting IT system. In: Kósa, I., Vassányi, I. (eds.): Health IT on New fundaments. [Fiziológiai paraméterek változása életmód támogató informatikai rendszer használata során. In: Kósa, I., Vassányi, I., (szerk.): Új alapokon az egészségügyi informatika.] A XXVIII. Neumann Kollokvium kiadványa. Veszprém, 2015. [Hungarian]

[15] Vassányi, I., Kósa, I., Karim, R. A., et al.: Effectiveness of mobile personal dietary logging. In: Kommers, P., Isaías, P. (eds.): Procedings of the 13th International Conference of e-Society. Madeira, Portugal, March 14-16, 2015.

[16] Lavinia lifestyle mirror. [Lavinia életmód-tükör.] http://www. lavinia.hu/ [Hungarian]

[17] Calorie-base. [Kalóriabázis.] http://kaloriabazis.hu/ [Hungarian]

[18] Mint. [Menta.] Mobile application. http://menta.gov.hu/ [Hungarian]

[19] Calorie-guru. [Kalóriaguru.] Online application. http://www. xn--kalriaguru-ibb.hu/ [Hungarian]
[20] MyFitnessPal. Mobile and online application. https://www.myfitnesspal.com/

[21] Lifesum. Mobile and online application. https://lifesum.com/

[22] Triabetes. Mobile and online application. http://triabetes.com/en/

[23] MySugr. Mobile and online application. https://mysugr.com/

[24] Chomutare, T., Fernandez-Luque L., Arsand E., et al.: Features of mobile diabetes applications: review of the literature and analysis of current applications compared against evidence-based guidelines. J. Med. Internet Res., 2011, 13(3), e65.

[25] Rodler, I., (ed.): New food compositon table. [Új tápanyagtáblázat.] Medicina Könyvkiadó, Budapest, 2005. Hungarian]

[26] American Diabetes Association: Foundations of care: education, nutrition, physical activity, smoking cessation, psyhosocial care, and immunization. Diabetes Care, 2015, 38(Suppl. 1), S20-S30.

[27] Dietary and Human Alimentation Professional Board: Dietary management of diabetes mellitus in adults. [Dietetikai Humán Táplálkozási Szakmai Kollégium: A diabetes mellitus dietoterápiájáról felnőttkorban.] NEFMI Protokoll, Budapest, 2010. [Hungarian]

[28] Kondrát, Gy. I.: Dietary management of diabetes mellitus. In: Figler, M., Kubányi, J. (eds.): Dietetics in GP practice. [A diabetes mellitus étrendi kezelése. In: Figler, M., Kubányi, J. (szerk.): Dietetika a háziorvosi gyakorlatban.] SpringMed Kiadó, Budapest, 2015. [Hungarian]

[29] Atkinson, F. S., Foster-Powell, K., Brand-Miller, J. C.: International tables of glycemic index and glycemic load values: 2008. Diabetes Care, 2008, 31(12), 2281-2283.

[30] Riccardi, G., Rivellese, A. A., R. Giacco, R.: Role of glycemic index and glycemic load in the healthy state, in prediabetes, and in diabetes. Am. J. Clin. Nutr., 2008, 87(1), 269S-274S.

[31] Marlett, J. A., McBurney, M. I., Slavin, J. L., et al.: Position of the American Dietetic Association: health implications of dietary fiber. J. Am. Diet. Assoc., 2002, 102(7), 993-1000.

[32] Evert, A. B., Boucher, J. L., Cypress, M., et al.: Nutrition therapy recommendations for the management of adults with diabetes. Diabetes Care, 2013, 36(11), 3821-3842.

[33] Vannice, G., Rasmussen, H.: Position of the Academy of Nutrition and Dietetics: dietary fatty acids for healthy adults. J. Acad. Nutr. Diet., 2014, 114(1), 136-153.

[34] Simopoulos, A. P.: Essential fatty acids in health and chronic disease. Am. J. Clin. Nutr., 1999, 70(3), 560S-569S.

[35] Sarkadi-Nagy, E., Bakacs, M., Illés, É., et al.: Hungarian diet and nutritional status survey - The OTAP2009 study. II. Energy and macronutrient intake of the Hungarian population. [Országos Táplálkozás és Tápláltsági Állapot Vizsgálat - OTÁP2009. II. A magyar lakosság energia- és makrotápanyag-bevitele.] Orv. Hetil., 2012, 153(27), 1057-1067. [Hungarian]

[36] Antal, M.: Nutrient requirements. In: Rodler, I. (ed.). New Food Compositon Table. [Tápanyagszükséglet. In: Rodler, L. (szerk.): Új tápanyagtáblázat.] Medicina Könyvkiadó, Budapest, 2005. [Hungarian]

[37] Population nutrient intake goals for preventing diet-related chronic diseases. In: Joint WHO/FAO Expert Consultation: Diet, nutrition, and prevention of chronic diseases. WHO Techn. Rep. Ser. 916 (TRS 916). Geneva, 2003.

[38] U.S. Department of Agriculture and U.S. Department of Public Health and Human Services: Key Elements of Healthy Eating Patterns. In: 2015-2020 Dietary guidelines for Americans. Washington, 2015.

[39] Lakatos, Cs., Surján, Gy.: Co-morbidities of type 1 diabetes mellitus in childhood: Comprehensive Hungarian population study. [Az 1-es típusú diabétesz társbetegségei gyermekkorban: egy teljes körû magyar populációs vizsgálat.] Interdiszciplináris Magyar Egészségügy, 2015, 14(4), 5-10. [Hungarian]

[40] Piette, J. D., Kerr, E. A.: The impact of comorbid chronic conditions on diabetes care. Diabetes Care, 2006, 29(3), 725-731.

(Szálka Brigitta,

Felsöörs, Bárókert u. 18., 8227 e-mail: szalka.brigitta@gmail.com) 